\title{
Influence of organ transplant controversies on corneal donation rates
}

\author{
Daniel Röck, Karl Ulrich Bartz-Schmidt and Tobias Röck* \\ Centre for Ophthalmology, University of Tübingen, Tübingen, Germany
}

\begin{abstract}
Aim: This study aimed to investigate the influence of organ transplant controversies on corneal donation rates at the University Hospital Tübingen.

Methods: Data from all hospital deaths from 2009 to 2015 were analyzed. During the 7-year period two vast German organ donor controversies occurred in the end of 2012 and 2014. An ophthalmic resident handled on a full-time basis the corneal donor procurement with stable methods. The rates of corneal donation were examined and evaluated.

Results: Among the 5712 deaths, consent for corneal donation was obtained in 711 cases. The mean annual corneal donation rate was $12.4 \%$ (range: $8.7 \%$ - $17.8 \%$ ). Since 2009, the donation rate per year could be increased with exception of 2013 and 2015. In the end of 2012 and 2014 two vast German organ donor controversies received worldwide attention. In the following years 2013 and 2015 corneal donation rate decreased significantly $(\mathrm{P}=0.02$ and $\mathrm{P}=0.0006)$.

Conclusion: German law regarding tissue collection is based on previous informed consent from the donor through a standard donor card or through verbal or written consent. In its absence, the next of kin may give his or her consent, but may not oppose any known wishes of the donor. Our study showed that organ donation controversies may influence the corneal donation rate significantly.
\end{abstract}

\section{Introduction}

Keratoplasty has been performed for over 110 years successfully and has been the most frequently performed transplant procedure worldwide [1]. Nonetheless in most countries there is a severe shortage of donor corneas [2]. It consists a rising demand for corneal grafts due to the older population and the increasing trend to endothelial keratoplasty procedures $[3,4]$.

Particularly, the procurement of donor cornea depends on functioning network between intensive care units and cornea bank [5], the availability of suitable donors [6,7] and the previous informed consent from the donor through a standard donor card or through verbal or written consent [8].

Confronted with the serious shortage of donor corneas we decided to investigate the influence of organ transplantation controversies on corneal donation rate at the University Hospital Tübingen from 2009 to 2015. In the end of 2012 [9] and 2014 [10] media reported on multiple German organ donation controversies including physicians in Germany [9-13]. These organ donor controversies received worldwide attention [11].

To the best of our knowledge, this is the first study about the influence of organ transplant controversies on corneal donation rates.

\section{Materials and methods}

Data from all hospital deaths at our University Hospital with 1500 beds from 2009 to 2015 were analyzed. No donor age limits were set and enucleation times up to 72 hours postmortem were accepted. The consent had been recorded. From 2009 to 2015 an ophthalmic resident handled on a full-time basis the donor screening, interviews with the next of kin, corneal donor procurement and retrieval. The rates of corneal donation were calculated and examined. This study was approved by the institutional review board of the University of Tübingen and adhered to the tenets of the Declaration of Helsinki.

\section{Statistical analysis}

Statistical analysis of the data was conducted using the Statistical Packages for the Social Science (SPSS 18.0). Quantitative variables were expressed as mean \pm standard deviation (SD). $\mathrm{P}<0.05$ was considered to be statistically significant.

\section{Results}

This retrospective study included 5712 hospital deaths. Consent for corneal donation was obtained in 711 cases. The male:female ratio was 61:39. Mean donor age was 70 years (SD 14, range 16-93). The mean annual corneal donation rate was $12.4 \%$ (range: $8.7 \%-17.8 \%$ ). The male:female ratio was 61:39. Mean donor age was 70 years (SD 14 , range 16 - 93). In 2014, the highest corneal donation rate of 17.8 $\%$ was achieved in contrast to the lowest in 2009 (8.7\%). Since 2009 , the donation rate per year could be increased with exception of 2013 and 2015. In the end of 2012 and 2014 multiple German organ donor controversies received worldwide attention. In the following years 2013 and 2015 corneal donation rate decreased significantly $(\mathrm{P}=0.02$ and

Correspondence to: Dr. Tobias Röck, M.D., Centre for Ophthalmology, University of Tübingen, Schleichstr. 12, D-72076 Tübingen, Germany, Tel: 00497071-2983721; E-mail: Tobias.Roeck@med.uni-tuebingen.de

Key words: cornea, organ donation controversies, tissue donors, corneal donor procurement, corneal donation

Received: April 28, 2016; Accepted: May 16, 2016; Published: May 19, 2016 
$\mathrm{P}=0.0006)$. Figure 1 presents annual corneal donation rate from 2009 2015. Table 1 shows the number of cornea donors and deaths per year and the rate per 100 deaths.

\section{Discussion}

Our study showed the influence of organ transplant controversies on corneal donation rate in 711 consecutive consent cases at the University Hospital Tübingen during a 7-year period.

In literature multiple factors contribute to loss of potential cornea donors: the imperfect identification of potential donors, the donor family has not been asked and the denial of consent by the potential donors family [14]. Muraine et al. [15] reported that potential donor identification and reaching relatives for verification the last will of the deceased implies a high degree of organization and a sufficient staff level [15].

Different studies demonstrated that measures can be taken to improve consent rates. It was recommended the interviewer did complete specific communication training and had more clinical experience $[16,17]$. A high positive response can be obtained from the donor's family when a trained and motivated interviewer manages the post-mortem cornea donation request $[18,19]$. Potential corneal donor identification is based on a functioning network between intensive care units and a cornea bank [5]. Regular advancement training intensifies this relationship. To the best of our knowledge, this is the first study about the influence of organ transplant controversies on corneal donation rates.

German law regarding tissue collection is based on previous informed consent from the donor through a standard donor card or through verbal or written consent. In its absence, the next of kin may give his or her consent, but may not oppose any known wishes

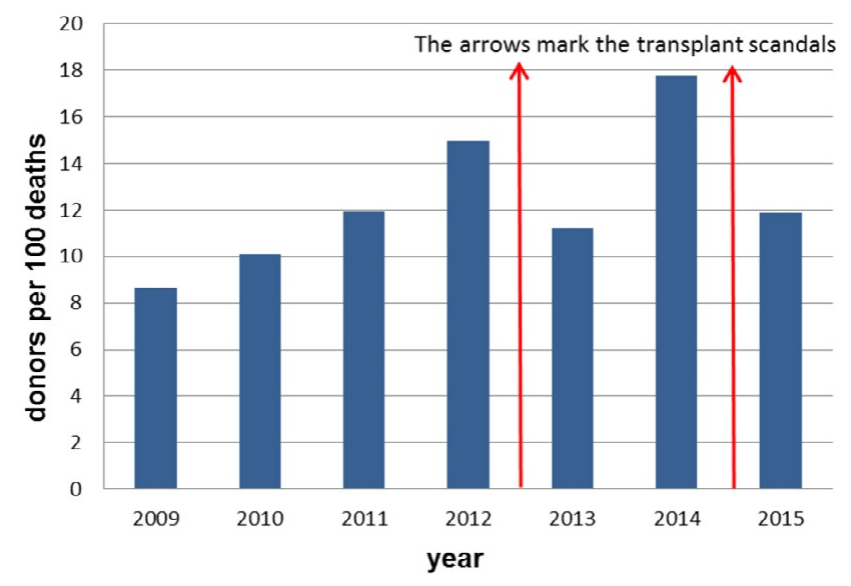

Figure 1. Annual corneal donation rate from 2009 to 2015: The mean annual cornea donation rate was $12.4 \%$ (range: $8.7 \%-17.8 \%$ ). Since 2009 , the donation rate per year could be increased with exception of 2013 and 2015. In the end of 2012 and 2014 multiple German organ donor scandals received worldwide attention. The arrows mark the organ donor scandals. In the following years 2013 and 2015 corneal donation rate decreased significantly $(\mathrm{P}=0.02$ and $\mathrm{P}=0.0006)$ of the donor. Under ideal circumstances, face to face would be the preferred setting of requesting consent. However, legal postmortem time constraints limit their ability to arrange face to face meetings [20,21]. A simple solution to increase the number of families contacted is to contact them by telephone [16]. The use of telephone increased overall cornea donation rates, mainly because of logistic improvements [20,21]. Furthermore, Geissler et al. [22] reported, that consent rates for cornea donation obtained via telephone interview increase with the interviewers' experience. Muraine reported a dramatic drop in face to face consent rates when an inexperienced ophthalmologist took part in their interviews [18] and Linyear et Tartaglia suggested that staff experience is a major contributor to a positive donation outcome [23].

Based on this knowledge since 2009 the donation rate per year could be increased with exception of 2013 and 2015. In the end of 2012 [9] and 2014 [10] multiple German organ donor controversies received worldwide attention. In the following years 2013 and 2015 corneal donation rate decreased significantly $(\mathrm{P}=0.02$ and $\mathrm{P}=0.0006)$. Because of not changing the setting of corneal tissue procurement and without changing standards in the whole study period we suspect that the decrease had been exacerbated by organ donation controversies including physicians in Germany who favored several patients for different reasons [9,11]. Hoisl et al. [12] reported that several hundred articles, which focused on the transplantation scandal, were published in the leading German newspapers between the end of 2012 and early 2013. This seems to be responsible for the decrease of the donation rate in 2013 .

At the German Heart Institute of Berlin a new scandal was uncovered and the topic flared up again in the media in the end of 2014. Physicians manipulated waiting lists. Incorrect statements were made about medical conditions and medicine wrongly prescribed so that patients appeared sicker than they were [13]. Jox et al. [24] showed a significant decrease in the number of organ donations in Germany caused by the transplant controversies. Especially between the end of 2012 and early 2013 and between the end of 2014 and early 2015 the media reported about the controversies. In the following years 2013 and 2015 the number of cornea donors at the University Hospital in Tübingen decreased significantly.

Nevertheless some points should be considered before drawing hasty conclusions. The main limitation of our evaluation is the limited comparability of these data with previous publications on the corneal donation rate. Almost all of our donors coming from cadaver deaths of the University Hospital in Tübingen with exception of few brain dead organ donors. Other cornea banks originating their donors from hospitals partially far away or from cadavers who died outside hospitals, what means that the donors died under uncontrolled conditions. Therefore they had a vast heterogeneity of the study population without stable methods of procedures and without stable contact persons. Sometimes they changed the methods during the study period, for example in situ corneoscleral disc excision versus whole globe enucleation. These facts could have an influence on the donation rate.

Table 1. Number of cornea donors and deaths per year: The table shows the number of cornea donors and deaths per year and the rate per 100 deaths. This study included 5712 hospital deaths. Consent for corneal donation was obtained in 711 cases. The mean annual corneal donation rate was $12.4 \%$ (range: $8.7 \%-17.8 \%$ ).

\begin{tabular}{|l|c|c|c|c|c|c|c|}
\hline Year & 2009 & 2010 & 2011 & 2012 & 2013 & 2014 & 2015 \\
\hline Donors & 64 & 79 & 93 & 124 & 96 & 150 & 105 \\
\hline Deaths & 738 & 783 & 779 & 829 & 856 & 844 \\
\hline Rate per 100 deaths & 8.7 & 10.1 & 11.9 & 15.0 & 11.2 & 583 & 17.8 \\
\hline
\end{tabular}


In our opinion the corneal donation rate may be influenced by sufficient staff levels of the eye banking team, a specific training of the eye bank resident performing the consent with the next of kin, motivation and experience of the resident, empathy in the grieving process and actual organ donation controversies.

In conclusion, our study showed that organ donation controversies may influence the corneal donation rate significantly.

\section{Acknowledgements}

Tobias Röck, Karl Ulrich Bartz-Schmidt and Daniel Röck participated in research design, in the writing of the paper, in the performance of the research and participated in data analysis.

\section{Competing interests}

None (no support from any organisation for the submitted work; no financial relationships with any organisations that might have an interest in the submitted work; no other relationships or activities that could appear to have influenced the submitted work).

\section{Funding statement}

This research received no specific grant from any funding agency in the public, commercial or not-for-profit sectors.

\section{References}

1. Seitz B, Langenbucher A, Naumann GO (2005) The penetrating keratoplasty. A 100year success story. Ophthalmologe 102: 1128-1136, 1138-1139. [Crossref]

2. Heindl LM, Riss S, Bachmann BO, Laaser K, Kruse FE, et al. (2011) Split cornea transplantation for 2 recipients: a new strategy to reduce corneal tissue cost and shortage. Ophthalmology 118: 294-301. [Crossref]

3. Eye Bank Association of America. Eye Banking Statistical Report. 2013 http://www. restoresight.org/wp-content/uploads/2014/04/2013_Statistical_Report-FINAL.pdf. Accessed 30 April 2016.

4. Lawlor M, Dobbins T, Thomas KA, Billson F (2006) Consent for corneal donation: the effect of age of the deceased, registered intent and which family member is asked about donation. Br J Ophthalmol 90: 1383-1385. [Crossref]

5. Röck T, Hofmann J, Thaler S, Bramkamp M, Bartz-Schmidt KU, et al. (2016) Factors that influence the suitability of human organ-cultured corneas. Graefes Arch Clin Exp Ophthalmol 254: 135-141. [Crossref]

6. McKeown DW, Bonser RS, Kellum JA (2012) Management of the heartbeating braindead organ donor. Br J Anaesth 108 Suppl 1: i96-107. [Crossref]

7. Gore SM, Taylor RM, Wallwork J (1991) Availability of transplantable organs from brain stem dead donors in intensive care units. BMJ 302: 149-153. [Crossref]
8. Abbott A (1997) German law could boost prospects for organ transplants. Nature 388: 4. [Crossref]

9. Hyde R (2012) German doctors call for reform after organ scandal. Lancet 380: 1135 [Crossref]

10. Dufner A, Harris J (2015) Trust and altruism--organ distribution scandals: do they provide good reasons to refuse posthumous donation? J Med Philos 40: 328-341. [Crossref]

11. BBC News (2013). German medicine rocked by Leipzig organ donor scandal. http:// www.bbc.com/news/world-europe-20897840. Accessed 07 January 2016.

12. Hoisl A, Barbey R, Graf BM, Briegel J, Bein T (2015) Assessment of the transplantation scandal by the media : scientific discourse analysis of selected German newspapers. Anaesthesist 64: 16-25. [Crossref]

13. Spiegel online (2014). Herzzentrum in Berlin: Behörden ermitteln wegen Betrugs be Spenderherzen. http://www.spiegel.de/gesundheit/diagnose/organspende-behoerdenermitteln-wegen-betrugsverdacht-in-berlin-a-987448.html. Accessed 07 January 2016.

14. Wiederhold C, Wilhelm F, Duncker GI, Bredehorn T (2001) Investigations on the cornea donation at the Martin-Luther-University Halle-Wittenberg. Klin Monbl Augenheilkd 218: 557-561. [Crossref]

15. Muraine M, Toubeau D, Menguy E, Brasseur G (2002) Analysing the various obstacles to cornea postmortem procurement. Br J Ophthalmol 86: 864-868. [Crossref]

16. Hermel M, Monhof K, Steinfeld A, Salla S, Hamsley N, et al. (2015) The Role of Specifically Tailored Communication Training Among Factors Influencing Consent for Cornea Donation Requested Via Telephone. Transplantation 99: 2223-2229. [Crossref]

17. Krieglstein TR, Welge-Lüssen UC, Priglinger S, Kampik A, Priemer F, et al. (2002) Consenting to cornea donation: influencing factors. Graefes Arch Clin Exp Ophthalmol 240: 816-821. [Crossref]

18. Muraine M, Menguy E, Martin J, Sabatier P, Watt L, et al. (2000) The interview with the donor's family before postmortem cornea procurement. Cornea 19: 12-16. [Crossref]

19. Tandon R, Verma K, Vanathi M, Pandey RM, Vajpayee RB (2004) Factors affecting eye donation from postmortem cases in a tertiary care hospital. Cornea 23: 597-601. [Crossref]

20. Gain P, Thuret G, Loup Pugniet J, Rizzi P, Acquart S, et al. (2002) Obtaining cornea donation consent by telephone. Transplantation 73: 926-929. [Crossref]

21. Rodríguez-Villar C, Ruiz-Jaramillo MC, Paredes D, Ruiz A, Vilardell J, et al. (2007) Telephone consent in tissue donation: effectiveness and efficiency in postmortem tissue generation. Transplant Proc 39: 2072-2075. [Crossref]

22. Geissler A, Gerbeaux PR, Maitrejean C, Durand-Gasselin J (2005) Cornea donation evaluation of a training session to obtain consent by telephone. Transplant Proc 37: 4634-4636. [Crossref]

23. Linyear AS, Tartaglia A (1999) Family communication coordination: a program to increase organ donation. J Transpl Coord 9: 165-174. [Crossref]

24. Jox RJ, Marckmann G, Assadi G. Organ Transplantation in Times of Donor Shortage Challenges and Solutions. International Library of Ethics, Law, and the New Medicine. Cham Heidelberg New York Dordrecht London: Springer. ISBN: 978-3-319-16440-3 (Print) 978-3-319-16441-0 (e-Book); 2015, page 187

Copyright: (C2016 Röck D. This is an open-access article distributed under the terms of the Creative Commons Attribution License, which permits unrestricted use, distribution, and reproduction in any medium, provided the original author and source are credited. 